Прегледни чланак

341.382:061.1EU

doi:10.5937/zrpfns54-27450

Tomislav B. Dagen, Ph.D.

Josip Juraj Strossmayer University of Osijek

The Academy of Arts and Culture in Osijek

tdagen@net.hr

\title{
LEGAL AND HISTORICAL VIEWS OF LEGAL SOURCES FOR THE ESTABLISHMENT AND BUILDING OF EEC/EU PEACE IN THE FORMER YUGOSLAVIA IN 1993 AND EUROPEAN REALITIES IN 2020
}

\begin{abstract}
The last peace mediation of the European Economic Community through European Political Cooperation, as well as the operationalization of the European Union's Common Foreign and Security Policy on 1 Novemeber 1993 in the territory of the former Yugoslavia will be reflected through the Action Plan. (Juppè-Kinkel Plan). Such final independent attempt by the EEC/EU to establish and build peace through peace mediation will have its stronghold in legal sources. The effects of peace mediation through the Action Plan will reflect the content and reach of legal sources and resulting mechanisms from the same sources. The failure of the Action Plan will give a new dimension to the CFSP's foreign policy action to establish and build peace among the conflicting parties through peace mediation. Accordingly, as the subject of research in this paper, the author will draw a parallel between 1993 and 2020 from a legal and historical perspective and through comparative, historical and method of analysis, and show whether, after almost three decades, since the last EEC/EU independent peace mediation effort for establishing and building peace in the former Yugoslavia, the EU, despite its desire to be a global factor in establishing and achieving peace in the world in accordance with the content and scope of the Treaty of Lisbon and other legal sources, is able to establish and build peace among the conflicting parties.
\end{abstract}

Keywords: European Union, Action Plan, Treaty of Lisabon, establishment of peace, peace mediation. 


\section{INTRODUCTION}

The war in the former Yugoslavia, specifically in the Republic of Croatia and the Republic of Bosnia and Herzegovina in the early 1990s will show and prove all the reality and content of the scope of legal and political action of the international community in the context of crisis management, peace achievement, as well as the possibility of finding a solution among the conflicting parties through international legal acts, especially by the European Economic Community (EEC), i.e. the European Union (EU). The failure of the EEC's previous attempts to establish peace through joint action with the United Nations and find a solution among the warring parties in the war-torn area of the former Yugoslavia (Vance-Owen Peace Plan, Owen-Stoltenberg Peace Plan) through international legal mediation mechanisms (mediation - Brijuni Conference) and through the conciliation process (conciliation - International Peace Conference - Hague Peace Conference, Carrington - Cutileiro Plan), will be a sufficient motive for the global proving of the EU as a global political force capable of managing the crisis and achieving peace in Europe as well as implementing its own foreign policy guidelines stemming from the Founding Treaties. Such facts will be decisive for the latest, independent European peace action in the context of establishing and building peace in the former Yugoslavia through the Action Plan (Juppeè-Kinkel Plan or Juppè Kinkel Initiative). Since the Maastricht Treaty or the Treaty on European Union ${ }^{1}$ entered into force on 1 November 1993, the Action Plan will also be a test of the content and scope of its own legal frameworks from which the mechanisms for establishing and building peace arise, which were thought to be able to influence the achievement of peace and finding solutions among the conflicting parties.

The failure of the 1993 Action Plan will result in the desired legal evaluation of the EU in the context of strengthening its own norms, from which the mechanisms of future EU action in establishing and building peace in Europe and the world will emerge. Despite the development of legal sources and the possibility of European peace action in the world, and especially in the time since the Lisbon Treaty entered into force, the EU will be given the opportunity to achieve that political maxim, which is to be a global player in terms of establishing and building peace in the world. Despite the normative content of the Lisbon Treaty, which will introduce reform innovations in the field of the Common Foreign and Security Policy, the Common Security and Defence Policy, as well as other legal sources arising from the same Treaty, which will provide the EU with various necessary mechanisms for foreign policy peacekeeping, the author will show the differentiation of legal sources by comparing and drawing a parallel between 1993 and 2020 . Differentiation of legal sources will refer to those sources that will give the necessary lume 35

${ }^{1}$ Maastricht Treaty, Treaty on European Union, [1992] OJ Official Journal of the C 191 Vo- 
legitimacy to EEC/EU peacekeeping in the process of establishing and building peace, and answer whether the development of legal sources, from which different EU peacekeeping mechanisms arise, can actually act in establishing and building peace among the conflicting parties.

Therefore, in the legal and historical analysis and analysis of the reality of the current situation, as well as in proving the thesis set out in this paper, the paper will be structured through a legal and historical overview of legal sources and their contents based on which the EEC/EU will launch an Action Plan through a review of the Action Plan and its effects, through a review of legal sources for the establishment and building of EU peace from 1993 to the Lisbon Treaty, and through a clear overview of the reality of the Lisbon Treaty and other acts providing a legal basis for peacebuilding (peace mediation, civil and EU military missions around the world) to show the real effects of legal sources and their content in the implementation of such action. In the concluding part, the author will give concluding remarks on the real achievements of EU action in the context of the possibility of establishing and building world peace arising from the content of legal sources, and assess whether after almost three decades since the last independent peace mediation, the European Union their content is able to establish and build peace in Europe and the world, and thus become a truly "Global Player", given the legal sources and their content.

\section{LEGAL AND HISTORICAL OVERVIEW OF EEC / EU LEGAL SOURCES FOR THE ESTABLISHMENT AND BUILDING OF PEACE IN 1993 IN THE FORMER YOUGOSLAVIA}

In terms of determining the context of the time and mode of action of the $\mathrm{EEC} / \mathrm{EU}$ in relation to the war-torn area of the Republic of Croatia and the Republic of Bosnia and Herzegovina, it is unquestionable that the EEC and later the EU in the early 1990s, embarked on a process of their own political and institutional building, contributed by the Maastricht Treaty or the Treaty on European Union, which will formalize the institutions of the future EU, which includes foreign policy action through the Common Foreign and Security Policy. The Action Plan was initiated by the French Foreign Minister Alan Juppè and the German Foreign Minister Klaus Kinkel and launched in the autumn of 1993. The question arises as to whether it was a reflection of the European Economic Community's single political cooperation and the EEC's last independent peace attempt or the first peace mediation of the newly formed Maastricht EU and its Common Foreign and Security Policy. ${ }^{2}$

\footnotetext{
${ }^{2}$ The French and German Foreign Ministers' initiative was launched after 1 November 1993 , and despite the fact that the Maastricht Treaty has been in force since the same day, the Action
} 
Therefore, in the context of determining the legal basis for launching the initiative, we should primarily look through the provision of Article 30, point 2a of the Single European Act in the chapter "TREATY PROVISIONS ON EUROPEAN CO-OPERATION IN THE SPHERE OF FOREIGN POLICY" which states the following: "The High Contracting Parties undertake to report to each other and consult on all foreign policy issues of general interest in order to ensure that their joint influence is exercised as effectively as possible through coordination, convergence of their positions and implementation of joint action", as well as through the provision of Article 30, point 3c, which states: "In order to ensure the rapid adoption of common positions and the implementation of joint action, the High Contracting Parties, shall, as far as possible, refrain from obstructing consensus-building and joint action which may result therefrom." 3 From the above provisions, we can clearly see which mechanisms of action in terms of establishing and building peace are available to the EEC.

In the further legal and historical elaboration of legal sources, and in order to be able to compare the mentioned period of foreign policy European peace mediation on the basis of legal sources and their contents with today's reality of legal sources and their scope, given that we have stated that this is a peace initiative from the end of 1993, we must look at it through the prism of the Maastricht Treaty. Since the rule of law is the fundamental principle of the EU action, it will be a conditio sine qua non of the CFSP in terms of building and establishing peace, or peace mediation of the EU in relation to the former Yugoslavia. Therefore, any future foreign policy action, including the EU peace mediation in relation to the war-torn area of the Republic of Croatia and the Republic of Bosnia and Herzegovina, had its legal basis in the legal sources of the EU Public Law, as well as in international legal determinants. By analyzing the sources of law, as well as their content, we must emphasize the introductory provisions of the Treaty on European Union which clearly provide the essential basis for future CFSP action in building and establishing peace in Europe and the world through peace mediations, especially through;

- the provisions of Article B, which state that "the Union shall set itself the following objectives - to establish its identity on the international stage, in particular by pursuing a common foreign and security policy, including the possible formulation of a common defence policy, which could eventually lead to a common defence";

Plan as a peace initiative will be published in the Official Bulletin of European Political Cooperation, while some official documents / reports discuss the implementation of the Treaty on European Union, Common Foreign and Security Policy on the example of the former Yugoslavia (example: European Council in Brussels - 29 October 1993 Presidency Conclusion, accessed 15 May 2020, https://ec.europa.eu/commission/presscorner/detail/en/DOC_93_7,), therefore the authors consider the legal sources for the European political cooperation of the European Economic Community and the Common Foreign and Security Policy of the European Union

${ }^{3}$ Single European Act, Official Journal of the European Communities No L 169, 29. 6. 1987. 
- and through the chapter "Common Foreign and Security Policy (CFSP)", the provisions of Title $\mathrm{V}$ of Article J.1, point 2, indent 3, which states the following: "The objectives of the Common Foreign and Security Policy are to preserve peace and strengthen international security in accordance with the principles of the United Nations Charter, as well as the principles of the Helsinki Final Act and the Paris Charter", as well as in point 3, indent 2 - "The Union shall achieve these objectives: by progressively implementing joint actions in areas where the Member States have important common interests in accordance with Article J.3." "4

In the formal sense, the primary legal determinant that will provide the legal basis and content of the action will be the provisions of Article J.2.1. and J. 3.1. of the Treaty in which a common position and joint action are used as instruments for implementing the common foreign and security policy. The joint action is determined by the said provision; "The Council decides, on the basis of the general guidelines of the European Council, that a certain issue is the subject of joint action. When deciding on the principles of joint action, the Council shall determine the specific scope of application, general and specific objectives of the Union for the implementation of that joint action and, if necessary, its duration and the means, procedures and conditions for its implementation." ${ }^{5}$ In addition to the above provisions, the EU will fully accept the provisions of international public law, which will be an additional legal basis for European policy of building and establishing peace through peace mediation and the Action Plan. ${ }^{6}$ In particular, the provision of Article 33 (1) of the UN Charter states the following; "The parties to any dispute whose continuation could jeopardize the maintenance of international peace and security, must first seek a solution through negotiations, polls, mediation - mediation, conciliation, arbitration, court settlement, recourse to regional institutions or agreements or other peaceful means of their own choice", as well as the provision of Article 52, paragraph 1: Nothing in this Charter shall preclude the existence of regional agreements or institutions for the settlement of matters relating to the maintenance of international peace and security which are appropriate for regional action, provided that such agreements or institutions and their operation are consistent with the purposes and principles of the United Nations. ${ }^{7}$ In the further legal and historical analysis of legal sources, the Hague Convention for the Pacific Settlement of International Disputes of 1907, where mediation is described as the action of one or more states not involved in the dispute, will provide an additional necessary legal basis for this European peacekeeping

\footnotetext{
${ }^{4}$ Maastricht Treaty, Treaty on European Union, op. cit.

${ }^{5}$ Ibid., Article J.3.1.

${ }^{6}$ For more on the sources of international public law, see Juraj Andrassy, et al., Međunarodno pravo I (Zagreb: Školska knjiga, 2010, 15 - 35)

${ }^{7}$ UN Charter, accessed 28 May 2020, https://www.un.org/en/charter-united-nations/
} 
action, by which they seek to reconcile opposing views and alleviate tensions between the states in dispute, in order to resolve the dispute peacefully. ${ }^{8}$

The aforementioned legal and historical overview of the determinants of European and international public law and determining the content of individual sources from which the peace mediation mechanism will emerge through the Action Plan, will clearly give us answers and reasons for failure of the last independent EEC peace plan or the first and last independent EU peace plan in relation to the war-torn area of the former Yugoslavia.

\section{EEC/EU ACTION PLAN - REFLECTION OF THE REALITY OF THE CONTENT AND REACH OF LEGAL SOURCES FOR ESTABLISHING AND BUILDING PEACE}

The lack of consensus or acceptance of peace plans by the international community among the warring parties in Bosnia and Herzegovina and the twoyear war in the same country, as well as the fact that progress has not been made in implementing Vance's plan for the Republic of Croatia, will be a sufficient reason the for the last independent attempt of the EEC, namely the EU's CFSP to act in the war-torn territory of the former Yugoslavia through peace mediation through the Action Plan or colloquially called the Juppeè-Kinkel Plan or the Juppè Kinkel Initiative. ${ }^{9}$ The historical sequence and development of events in the former Yugoslavia, and the failure of previous peace plans, and especially the failure of OwenStoltenberg's Peace Plan from July/September 1993 ("Invincible Plan") will result in a European peace initiative. European action in the process of building and establishing peace will be preliminary initiated by the Conclusion of the Presidency of the Council of the EU of 26 October 1993 on the implementation of the Treaty on European Union, in such a way that Chapter II - Common Foreign and Security Policy, subchapter "iv" states that "the priority of this policy is to define the conditions and joint actions, which includes seeking a negotiated and lasting solution to the conflict, and to contribute to the implementation of the peace plan and support humanitarian action." 10 Clear determinants of EU foreign policy in relation to the former Yugoslavia (the author in this part of the paper uses the term "former Yugoslavia" since the EU in its Conclusion of 26 October 1993 uses the same

\footnotetext{
${ }^{8}$ Handbook on the Peaceful Settlement of Disputes between States, United Nations, New York, 1992.

${ }^{9}$ For more on the chronology of peace mediations and the work of the international community in the former Yugoslavia, see Julian Bergmann, The European Union as International Mediator, Brokering Stability and Peace in the Neighbourhood (Palgrave Macmillan, Palgrave Studies in European Union Politics, Switzerland, 2020), 3 and 4.

${ }^{10}$ Conclusions of the Presidency of the Council of the EU of 29 October 1993. Europen Council in Brusells - 29 October 1993 Presidency Conclusions, author's comment.
} 
term and meaning, author's comment) based on defined legal sources that will provide the necessary legal basis for action, will be followed by the initiative of the Ministers of Foreign Affairs of the Republic of France Alain Juppē and FR Germany Klaus Kinkel, named EU Action Plan or Juppē- Kinkel Plan/Initiative. On 7 November 1993, the aforementioned ministers will send a letter to Willy Claes, President of the Council of the EU and Minister of Foreign Affairs of the Kingdom of Belgium, outlining a proposal for a peace initiative or the future Action Plan. ${ }^{11}$ In their Initiative, namely in their letter, the Ministers will state their "reflections" with a view to implementing the Common Foreign and Security Policy, where the "Twelve" should quickly develop a coherent common policy for a lasting truce and peace in the former Yugoslavia. An initiative or "reflections" in terms of peaceful resolution of the conflict would be to launch a global "action" within the Conference on the Former Yugoslavia, which would later take the form of a new initiative or international mechanism for peaceful resolution of the conflict called the Contact Group. The ministers also saw the solution for achieving peace in Bosnia and Herzegovina in the acceptance of the "Geneva Package" and the Owen-Stoltenberg Plan from the "Invincible", noting that there is no possibility for one or two entities to withdraw from the Union of Bosnia and Herzegovina, thus fully supporting the totality and integrity of Bosnia and Herzegovina, and at the same time leads to the full application of international legal provisions on the inviolability of borders and the principle of uti possidetis de iuris. The initiative included correcting the map within Bosnia and Herzegovina, namely the parties to the conflict. More specifically, it included the withdrawal of Bosnian Serbs from certain territories and the allocation of 3 to $4 \%$ of territory to Bosnian Muslims, which would condition such a gradual lifting of economic sanctions on FR Yugoslavia. ${ }^{12}$ In relation to the Republic of Croatia, the Initiative referred to the fact that Serbs would accept the "modus vivendi" for the Republic of Croatia, which the two ministers explained in the following way in the Initiative; "The risk of war in the "regions" is increasing. Since we cannot reach a final solution quickly at the moment, we must first focus on a ceasefire and measures in accordance with Security Council Resolution 847, which is a modus vivendi that excludes the danger of war and which is also a middle step towards a final solution."13

Following a ministerial initiative, the EU adopted a part of the proposed Initiative for the Former Yugoslavia on 22 November 1993. ${ }^{14}$ In terms of content, the

${ }^{11}$ Lord Owen's archival materials resulting from peace mediation activities in the former Yugoslavia are stored at the University of Liverpool/The Balkan Odyssey Digital Archive, accessed 2 March 2020., http://sca-arch.liv.ac.uk/ead/html/gb141boda-p1.shtml\#boda.1.05.1.

For more on the source see Tomislav Dagen, Pravnopolitički mehanizmi za sprječavanje sukoba i postizanje mira na prostoru bivše Jugoslavije od 1990. - 1995. (PhD Thesis, Doctoral School of University of Osijek, Osijek, 2018), 229.

${ }^{12}$ Ibid. Also, for more on the proposed ministerial initiative and Action Plan see Christoph Bluth, Germany and the Future of European Security (Macmillan Press LTD, London, 2000), 93.

${ }^{13}$ Ibid.

${ }^{14}$ EPC bulletin, Vol 9, 1993, 551, 552. 
EU will initially base its action in building and establishing peace among the conflicting parties on launching humanitarian action and assistance to Bosnia and Herzegovina, as well as holding a joint meeting of the presidents of all warring parties in Geneva on November 29, 1993. From the above, it is possible to clearly conclude the substantive achievements of EU action in building and establishing peace since its establishment, namely since the institutional formation of the CFSP. Considering the development of the situation and the failure to achieve peace, as well as the agreement between the parties to the conflict in Bosnia and Herzegovina, and regarding the situation in the Republic of Croatia ${ }^{15}$, with the "Declaration on the Former Yugoslavia" of 10/11 December 1993, the EU fully accepted the proposed initiative or plan of the two ministers, which nevertheless made a certain step forward in the content and operation of the CFSP. With the aforementioned Declaration, the emphasis is placed on the acceptance of the peace package, provided that by accepting it, economic sanctions against the FR of Yugoslavia will be lifted. ${ }^{16}$ Since the proposed initiative and the plan were not accepted, the EU will reaffirm the initiative in the form of an Action Plan on 22 December 1993, and reiterate its emphasis on negotiations and their conditionality with economic sanctions against FR Yugoslavia. ${ }^{17}$

In addition to diplomacy and negotiations with the co-chairs of the Peace Conference on the Former Yugoslavia, the EU negotiated with all parties to the conflict in Bosnia and Herzegovina, especially with the Presidents of Croatia and Serbia, as confirmed by Lord Owen's notes. According to the same records, negotiations lasted from 12 November 1993, until the final failure of the proposed Action Plan and immediate confirmation of the same on 10 February $1994^{18}$, when it became apparent that the map problem and the lack of US support for the proposed plan affect its acceptance by the conflicting parties, especially by Bosnian Muslims and Serbs. Therefore, the modus vivendi plan for UNPA zones and the Republic of Croatia, which was an integral part of the Action Plan, was not implemented in the Republic of Croatia. ${ }^{19}$

${ }^{15}$ In his memoir, Vladislav Jovanović, former Serbian Former Minister, said the following about the failure of Geneva negotiations; "Faced with the difficulties of Bosnian Serbs to accept the Owen-Stoltenberg Plan, the European Union, at the initiative of German Minister Klaus Kinkel and his French counterpart Alain Juppeè, came out at a large plenary meeting in Geneva in late November 1993 with its new proposal, the so-called "EU Action Plan", but it was not a success, because Karadžić remained in his positions ....". For more on the failure of the Geneva Conference, see Vladislav Jovanović, Rat koji se mogao izbeći, (Nolit, Beograd, 2008), 167.

${ }^{16}$ EPC bulletin, 591, 592.

${ }^{17}$ Ibid., 611.

${ }^{18}$ For more on the failure of the European peace initiative or Action Plan, see Roy H. Ginsberg, The European Union in International Politics; baptims by fire, (Rowman\&Litllefield Publisher, 2001), 63.

${ }^{19}$ On diplomatic activities and diplomacy of the European Union and co-chairs through the International Conference on the Former Yugoslavia from the moment of the initiative of the two 
The use of negotiation and peace mediation will prove insufficient in terms of the implementation of the proposed peace plan, as well as in terms of the desired construction and establishment of peace among the conflicting parties. The reason for this must primarily be seen in the applied legal sources, as well as in their content and scope, from which the EEC/EU could not implement its own positions, proposals, opinions and decisions among the parties to the conflict. We could also say that the EEC/EU was limited to only some mechanisms, by the conditionality with which it could possibly act towards one of the parties to the conflict, for example by imposing economic sanctions, which stemmed from the provision of Article 113 of the EEC Treaty and from the provisions of Article J.3.1. of the Treaty establishing the EU. ${ }^{20}$ The inability to find a peaceful solution among the conflicting parties in Bosnia and Herzegovina, as well as non-acceptance of the modus vivendi idea for the Republic of Croatia, with a clear historical overview of legal sources and content and scope on which the EEC/EU could act in peacebuilding, will portray the EU as an even more uncompetitive global political force in establishing and building peace in Europe and the world from the first half of the 1990s. The real reach of European political power in a global sense can be clearly seen through the words of the former Minister of Foreign Affairs of the Kingdom of Belgium, who says the following: "The European Union is an economic giant, a political ant and a military dwarf." 21

\section{EUROPEAN REALITY(IES) IN 2020 - CONTENT AND REACH OF LEGAL SOURCES FOR THE ESTABLISHMENT AND BUILDING OF PEACE - PEACE MEDIATIONS, MILITARY AND CIVILIAN MISSIONS IN THE WORLD}

\subsection{Legal sources for the establishment and building of EU peace from 1993 to the Lisbon Treaty}

Based on a clear and unambiguous presentation of the failure of EEC/EU action in establishing and building peace through peace mediation among the conflicting parties in the former Yugoslavia since the end of 1993, the reality of

\footnotetext{
ministers to the conclusion that the Action Plan is "dead" see David Owen, Balkanska odiseja (Hrvatska sveučilišna naklada, Croatian Institute of History, Zagreb, 1998), 276 - 303.

20 The Treaty establishing the European Economic Community/The Treaty of Rome, accessed 8 March 2020, http://eur-lex.europa.eu/legal-content/HR/TXT/?uri=CELEX:11957E/TXT

${ }^{21}$ Mark Eyskens, former Minister of Foreign Affairs of the Kingdom of Belgium stated the following for "The New York Times": "The European Union is an economic giant, a political ant and a military dwarf.", “Gulf Figting Shatters Europeans' Fragile Unity", “The New York Times”, 1991, accessed 26 February 2020, http://www.nytimes.com/1991/01/25/world/war-in-the-gulfeurope-gulf-fighting-shatters-europeans-fragile-unity.html
} 
European peacekeeping either through peace mediation or civilian and military missions in 2020 will portray the EU as a "potential" global political player, or as Tardy states in his paper "in the last twenty years, the European Union has become a true actor in crisis management" 22 or as the EU would state in its official publications; "Given the increasingly complex international environment, the European Union needs to step up its action to increase its ability to prevent conflict, build peace and strengthen international security." ${ }^{23}$ Following these views, Juncos and Blockmans in their paper claim the following; "Over the last two decades, the European Union has become increasingly involved in conflict prevention and the promotion of sustainable peace beyond its borders. It is said that the EU's potential to contribute to conflict prevention and peace-building is particularly promising given the wide range of instruments and resources that can be mobilized for EU external action." ${ }^{24}$ By accepting the above analyses of individual authors, as well as the determinants of the European Commission, it becomes clear that the EU in its foreign policy activities, as in 1993, is dedicated to the Union's action in peace mediation and action in a global environment as its primary foreign policy goal. Such premises clearly indicate the diversity and possibilities of European global positioning and action from the establishment of the EU to the present day, primarily due to normative regulation, and thus the breadth of the content of EU action. This is recognized by Manners in his paper, and on the basis of the above he introduces the term Normative Power Europe (NPE). ${ }^{25}$

In terms of the development of the Common Security and Defence Policy as a legal basis, namely a mechanism of future European foreign policy action in establishing and building peace between the conflicting parties, i.e. in crisis hotspots and crisis management, the drawing of parallel between 1993 and 2020 will be influenced by the events of the 1990s, as we have noted earlier. More specifically, the phasing of the European Security and Defence Policy as part of the Common Foreign and Security Policy will take several stages and time. As the first stage of development under the Common Security and Defence Policy, Rudolf states; "Encouraged by the ineffectiveness and failure of EU policy to prevent and quell armed conflicts in the former SFR Yugoslavia, the Amsterdam Treaty of 1997, Member States strengthened mutual cooperation to pursue a common foreign and

${ }^{22}$ Thierry Tardy, "The European Union and UN Peace Operations: What Global-Regional Peace and Security Partnership" in United Nations Peace Operations in a Changing Global Order, eds. Cedric de Coning, Mateja Peter, (Palgrave Macmillan, 2019), 231.

${ }^{23}$ Publication of the European Commision, European Peace Facility, 13 June 2018.

${ }^{24}$ Ana E. Juncos, Steven Blockmans, "The EU's role in conflict prevention and peacebuilding: four key challenges", Global Affairs, Routledge, Volume 4 (2018): 131, https://doi.org/10.1080/ 23340460.2018.1502619

25 Trineke Palm, Ben Crum, "Military operations and the EU's identity as an international security actor”, European Security, Vol 28, No 4, (2019): 514, https://doi.org/10.1080/09662839.2 019.1667769 
security policy. To that end, the function of the EU High Representative for Foreign Affairs and Security Policy has been established." ${ }^{26}$ A further step in the formal construction of the Common Security and Defence Policy, on the basis of which the first European military and civilian missions around the world will be launched, will take place at the EU summit in Cologne, where the Declaration will introduce the novelty and the term Common European Policy on Security and Defence. The EU was directly authorized to carry it out, and it was agreed that the EU would have access to part of NATO's military assets needed to carry out its own tasks, if and when NATO members were not interested in carrying them out. ${ }^{27}$ Such a fact, as well as the fact that the Declaration with the EU Summit of December 1999 in Helsinki will establish the "European Rapid Reaction Force" (RRF) will give the EU both normative and substantive-functional content and power in establishing and building peace, finding peace solutions, which it did not have in the past. ${ }^{28}$

A further legal source that will be a precursor to today's sources, and which will provide the EU with a legal basis in establishing world peace starting in 2003, will be the Treaty of Nice. Unlike the Treaty of Amsterdam, the European Security and Defence Identity will become an integral part of the EU's Common Foreign and Security Policy, and will give European engagement in world peace a stronger

${ }^{26}$ Davori Rudolf Jr., ,Zajednička sigurnosna i obrambena politika Europske unije prema Lisabonskom ugovoru“, Proceedings of the Faculty of Law in Split, yr. 51, No. 3 (2014): 559., and according to the Treaty of Amsterdam (signed on 2 October 1997, entered into force on 1 May 1999) and Radovan Vukadinović and Lidija Čehulić: Politika europskih integracija (Zagreb: Topical, 2005), 256.

The provision of Article J.8.3. of the Treaty of Amsterdam amending the Treaty on European Union, Treaties establishing the European communities, and related acts claim the following: "The Presidency shall be assisted by the Secretary-General of the Council, who shall act as High Representative for the Common Foreign and Security Policy." For more see, Treaty of Amsterdam amending the Treaty on European Union, the Treaties establishing the European Communities and certain related acts, OJ EC, C 340/01, 10 November 1997

Also, the fact that the failure of the European Union in the former Yugoslavia was crucial for launching a new policy, new mechanisms with which it will be able to manage crises is visible in the text on the official website of the European Union entitled "EU Missions and Operations as part of the EU's Common Security and Defence Policy (CSDP)" stating the following: "In the midst of the conflict in the Western Balkans in the 1990s, the EU and its Member States decided that the EU should be able to plan and conduct its own missions and operations. Steps have been taken to establish the necessary decision-making bodies, as well as structures for planning, command and control arrangements." For more see, EU Missions and Operations As part of the EU's Common Security and Defence Policy (CSDP):, accessed 21 April 2020., https://www.eca.europa.eu/sites/ eca-audit defence/EN/Documents/EU\%20Missions\%20and\%20Operations.pdf

${ }^{27}$ Cologne European Council, Presidency Conclusions. Annex III. [ON-LINE]. [s.1.]: [06.06. 2003]. Press: 0 Nr: 150/99

${ }^{28}$ Conclusions of the Helsinki European Council: extract concerning preparations for enlargement (10-11 December 1999), accessed 1 April 2020., https://www.europarl.europa.eu/summits/ hel1_en.htm 
character and support by fully amending the existing Article 17, paragraph 2 of the founding Treaty with Article 1, which will read; "The issues covered by this article include humanitarian and rescue tasks, peacekeeping tasks and combat force tasks in crisis management, including peace-building." ${ }^{29}$ Based on the aforementioned reform character of the Treaty of Nice, further legal and operational force will be given by the European Security Strategy/Secure Europe in a Better World of December 2003, which will clearly show European public policies for peace and conflict resolution both in the "neighborhood" and in the world. ${ }^{30}$ An additional importance in building European foreign policy credibility and determination in global positioning compared to 1993 will be the fact the strengthening of European defence powers and mechanisms that will be able to implement European peacekeeping operations, as NATO states in its Review; "The EU intends to absorb the Western European Union (WEU) in the near future, create a European Rapid Reaction Corps of 50,000-60,000 troops by 2003 for operations such as peacekeeping and regional crisis management, and establish appropriate decision-making structures (including Standing Committee on Political and Security Affairs, Military Committee and military personnel)." ${ }^{31}$

Following these legal sources, and reforming both legal sources and introducing mechanisms that will be able to implement declaratory decisions, the EU will start a new process of global presence in the world, namely participation in peacebuilding through military and civilian missions starting from 2003 (Macedonia and DR Congo). ${ }^{32}$

\subsection{Reality of EU Legal Sources for Establishing and Building Peace after the Lisbon Treaty - Realities of 2020}

Through a legal and historical overview of the development of legal sources and their content from which the legitimacy and mechanisms of European peace action in establishing and building peace in Europe and the World since 1993 will emerge, the reality of 2020 and the EU's participation in 34 civilian and military missions since 2003, as well as the current existence of 18 EU civilian and military peacekeeping missions in the world, will prove the evaluation of legal sources that

${ }^{29}$ Treaty of Nice amending the Treaty on European Union, the Treaties establishing the European Communities and certain related acts, signed at Nice, 26 February 2001, OJ EC, C 80, Volume 44, 10 March 2001

${ }^{30}$ European Security Strategy/ A SECURE EUROPE IN A BETTER WORLD, COUNCIL OF THE EUROPEAN UNION Brussels, 8 December 2003, 15895/03

${ }^{31}$ ESDI, Separable but not separate?, 1 July 2000/ NATO Review, accessed 15 April 2020 https://www.nato.int/docu/review/articles/2000/07/01/esdi-separable-but-not-separate/index.htm

32 IN-DEPTH ANALYSIS, CSDP Missions and Operations, European Parliament, January 2020., pp. 5. And EU in the World, accessed 17 April 2020, https://eeas.europa.eu/headquarters/ headquarters-homepage/area/geo_en 
will support European peace efforts, and at the same time give it the necessary strength (power) in such action. ${ }^{33}$ In identifying the sources of public law that will enable the EU to achieve its role as a "global player", they should primarily cite the determinants of the European Union's Global Strategy for the European Union's Foreign and Security Policy in 2016, which states the following; "Without global standards and ways to put them into practice, our vital interests are at stake: peace, security, prosperity and democracy. Guided by the values on which it was founded, the EU is committed to a world order based on international law, which includes the principles of the UN Charter, which ensure peace, human rights, sustainable development and lasting access to global common goods ...... A multilateral order based on international law, which includes the principles of the UN Charter and the Universal Declaration of Human Rights, is the only guarantee of peace and security in one's own country and abroad." ${ }^{4}$ The Lisbon Treaty will provide a legal step forward in global positioning and in terms of providing a broader content of mechanisms that will support EU peacekeeping operations in relation to the establishment and building of peace compared to 1993 and other founding treaties. It clarifies the role of the EU in the field of the common foreign and security policy, and will formally, legally and institutionally introduce a novelty within the Common Foreign and Security Policy, namely the Common Security and Defence Policy (CSDP) as an integral part of the Common Foreign and Security Policy. On the importance of the Common Security and Defence Policy and its role, on the official website of the European Parliament, the Common Security and Defence Policy (CSDP) is defined as a mechanism or framework for the political and military structuring of the European Union and its military and civilian missions and operations abroad. The institutional aspects of this policy are reflected in the provisions of the Lisbon Treaty, which clearly describes the stronger role of the European Parliament, while the Common Security and Defence Policy strategy is laid down as we stated in the European Union Global Strategy of 2016.

Furthermore, the reason for the introduction of the Common Security and Defence Policy is the necessity for strategic and operational changes in order to respond to security challenges and meet the demands of citizens for stronger action by the European Union. ${ }^{35}$ In addition to the fundamental provision of Article 3 of the Lisbon Treaty, which clearly and unambiguously sets out the European Union's foreign policy goal; "the Union's goal is to promote peace, its values and the wellbeing of its peoples", the necessary legal force for the operational functioning of the Common Foreign and Security Policy and the Common Security and Defence

${ }^{33}$ Ibid., 4.

${ }^{34}$ Global Strategy for the European Union's Foreign and Security Policy "Shared Vision, Common Action: A Stronger Europe”, EU Summit 28 June 2016, pp. 11.

${ }^{35}$ European Parliament, Common Foreign and Security Policy, accessed 26 April 2020, https:// www.europarl.europa.eu/factsheets/hr/sheet/159/zajednicka-sigurnosna-i-obrambena-politika 
Policy, a normative step forward will be the following provisions of the Lisbon Treaty which explicitly note the normative and substantive differentiation and breadth of mechanisms in the context of the founding treaties in 1992 (1993) and 2007 (2020), in such a way that the provisions:

- with Article 21 (2) the Union establishes and implements common policies and measures and seeks to achieve a high degree of cooperation in all areas of international relations in order to: preserve peace, prevent conflicts and strengthen international security, in accordance with the objectives and principles of the United Nations Charter, the Helsinki Final Act and the Paris Charter, including those relating to external borders

- with the second subparagraph of Article 24 (1), the Union establishes and implements the institutional formation of the High Representative of the Union for Foreign Affairs and Security Policy and the Member States in accordance with the Treaties

- with Article 38 (2), the Union establishes a Political and Security Committee which, under the responsibility of the Council and the High Representative, exercises political control and strategically directs the crisis management operations referred to in Article 43

- with Article 42 (1), which states that the the Common Security and Defence Policy (CSDP) will provide the Union with "operational capability based on civilian and military means". The Union may use them in missions outside the Union to preserve peace, prevent conflicts and strengthen international security in accordance with the principles of the United Nations Charter

- with Article 42 (3), where the European Defence Agency for the development of defence capabilities, research, acquisition and armament is institutionally established as well as

- with Article 43 (1) which clearly and precisely provides the necessary "power" for the implementation of the peace agreements and solutions reached, which arise from peace mediation or the application of international legal provisions; "The tasks referred to in Article 42 (1) during which the Union may use civilian and military means shall include joint disarmament operations, humanitarian and rescue tasks, military advisory and assistance tasks, conflict prevention and peacekeeping tasks, crisis management tasks, including the establishment of peace and post-conflict stabilization." 36

In addition to normative, substantive and structural differentiation in the context of drawing parallels between 1993 and 2020 in conflict prevention, the establishment and building of EU peace is made up of certain mechanisms as products of the normative action arising from the Lisbon Treaty. Since the operational procedures, namely operational mechanisms in peacebuilding, i.e. in peace me-

${ }^{36}$ Treaty of Lisbon amending the Treaty on European Union and the Treaty establishing the European Community [2007] OJ C 306/01 
diation or civilian and military missions, have emerged from legal sources, in the context of peace building and conflict prevention as a major part of the Common Security and Defence Policy the EU will use a wide range of external instruments to assist in conflict prevention and peacebuilding. Some of these instruments or the possibility of using mechanisms, in Herrberg's view, continue to be international institutes of peacekeeping, such as the United Nations, regional organizations and the African Union. ${ }^{37}$ In addition to Herrberg's view, the most significant mechanisms stemming from legal sources are listed below, which the EU can use in the context of peacebuilding, compared to 1993;

- conflict prevention mechanism, which includes mechanisms for early identification of the risk of violent conflict and closing the gap for early action; Improved understanding of conflict situations (root causes, actors and dynamics); Improved identification of the spectrum of opportunities for action in the EU; Conflict-sensitive external assistance programming

- mediation and dialogue mechanism. ${ }^{38}$

As Juncos and Blockmans state, the four key challenges or mechanisms of its external conflict prevention that have changed the historical practice of European peacekeeping in institutional terms are; bridging the gap of early warning and reaction, encouraging cooperation with other international partners, improving civil-military coordination in conflict prevention and peacebuilding, and how to protect the local population. ${ }^{39}$ On bridging early warning and reaction gap, as an EU mechanism in external conflict prevention policy, the Council will, in its Conclusions of 20 June 2011, elaborate on the mechanism of such action. ${ }^{40}$ Perhaps in the wake of the above, which has changed the historical practice of the EU in peacekeeping, Väyrynen notes in his research as the added value of the European Union by which it is recognizable in the peaceful settlement of disputes and mediation. Therefore, the author cites mechanisms that will enhance the role of the EU as a global mediator. In this sense, she lists three models of EU mediation activity and the fact that the EU uses its doctrine, incentives and conditionality both towards the parties to the conflict and the desired outcome of the mediation process, depending on whether the EU favors a common solution within a single state, a solution for several countries or a solution for two countries. In the first model,

${ }^{37}$ Antje Herrberg, "International Peace Mediation: A New Crossroads for the European Union”, in: ISIS Europe, ISIS Europe and Geneve Centre for the Democratic Control of Armed Forces, ed. Philip Vorre, (Brussels: 2012), 15.

${ }^{38}$ Conflict Prevention, Peace Building and Mediation, accessed 10 May 2020, https://eeas. europa.eu/topics/conflict-prevention-peace-building-and-mediation/426/conflict-prevention-peacebuilding-and-mediation_en

39 Juncos, Blockmans, The EU's role in conflict prevention and peacebuilding: four key challenges, 132, 133.

${ }^{40}$ Conflict Prevention - Council Conclusions, COUNCIL OF THE EUROPEAN UNION, Brussels, 20 June 2011 
the EU mediates in favoring a solution with one state despite the danger of creating state dysfunction, in the second it can favor one of the parties to the conflict and isolate the other to force the other to return to the negotiating table, and in the third the EU concludes that it must recognize secession and aims to put pressure on both sides in the conflict equally. ${ }^{41}$

In terms of peacebuilding, mediation, as an international legal mechanism for conflict prevention and peacemaking, will be part of the EU's international preventive diplomacy and an integral part of the EU's conflict prevention and peacebuilding tools for conflicting countries according to the official EU statement. Therefore, in 2009, the EU will develop its own capacity to support mediation, based not only on the legal document, but also on the guidelines established by the mechanism of the Concept on Strengthening EU Mediation and Dialogue Capacities. ${ }^{42}$ The adopted text of the Concept on Strengthening EU Mediation and Dialogue Capacities will be the legal basis for future EU peace mediations in peacebuilding, and will give it additional international legal credibility in peace mediations..$^{43}$ In the text of the mentioned document, the EU unequivocally defines international legal mechanisms for peaceful settlement of disputes through mediation and dialogue, and in the same document it states the roles of two key EU mechanisms in the implementation of international legal mechanisms for conflict prevention and states: "Mediation is a way of assisting in negotiations between conflicting parties and transforming conflicts with the support of an acceptable third party. The general objective of mediation is to enable the parties to the conflict to reach agreements which they consider satisfactory and ready to be implemented. Specific objectives depend on the nature of the conflict and the expectations of the parties and mediators. The primary objective is often to prevent or end violence by cessation of hostility or ceasefire through an agreement. Mediation is an efficient and cost-effective instrument for conflict prevention, transformation and resolution-making. It is a relevant feature of crisis management at all stages of state-to-state conflict: before it escalates into armed conflict, after the outbreak of violence and during the implementation of peace agreements." ${ }^{4}$

${ }^{41}$ Tarja Väyrynen, “The higher cause of peace': what could and should the Nordic countries contribute to the development of conflict mediation in the EU context?", The Nordic countries and the European Security and Defence Policy, eds. Alison Bailes, J.K, Herolf Gunilla and Bengt Sundelius, Bengt (Oxford University Press, 2006), pp. 225.

42 Council of the European Union, Concept on Strengthening EU Mediation and Dialogue Capacities, Brussels, 10 November 2009

${ }^{43}$ Johannes Schachinger, "European External Action Service engagement in mediation and mediation support" in: Strengthening the EU's peace mediation capacities. Leveraging for peace through new ideas and thinking, Tanja Tamminen ed. (Ulkopoliittinen instituutti, Utrikespolitiska institutet, The Finnish Institute of International Affairs, Helsinki, 2012), 17.

${ }^{44}$ Ibid., 2, 3 and 4.

The notion of mediation is also described and defined by Bergmann in his work, who defines mediation as a conflict management instrument that can be applied to any type of conflict. On 
Based on the above definition of mediation by the EU, in order to have a clearer picture of the legal sources from which the EU peacekeeping actions in the world in 2020 will emerge, and in relation to 1993 and the launched Action Plan, the text of the Concept on Strengthening EU Mediation and Dialogue Capacities describes and lists mechanisms for supporting the process of mediation and implementation of peace agreements. The text states that the mediation process has at its disposal a number of civilian and military crisis management instruments, as well as trade and other tools that promote the development of each country, which are available to the EU. For the coordination of this mechanism, the Political and Security Committee is mentioned as a key element not only in the coordination, but also in the implementation of this mechanism. Also, in the same text, the Dialogue is defined as an open process aimed primarily at creating a culture of communication and seeking mutual relations, which leads to building self-confidence and improving interpersonal relations, as well as understanding the representatives of opposing parties, which in turn can help prevent conflict and be a means of reconciliation and peacebuilding. A successful dialogue can settle the conflict and make formal mediation unnecessary. ${ }^{45}$

In further systemic and legal and historical connection of legal sources and mechanisms that will enhance the EU's foreign policy peacekeeping in the establishment and building of peace between the conflicting parties and in general show it different from 1993, the EU will elaborate and additionally, through the legal sources of European public law, provide a legal basis for peacekeeping mechanisms with all legal and other acts deriving from the Lisbon Treaty. In concrete terms, the EU will institutionally establish the Foreign Policy Instruments (FPI) as a service of the European Commission. ${ }^{46}$ As one of the foreign policy instruments, it will adopt a Regulation no. 230 of 2014 of the European Parliament and of the Council of 11 March 2014 establishing the Instrument Contributing to Stability and Peace (IcSP), which will have its legal basis in Articles 209 and 212 of the Treaty on the functioning of the European Union. The 2014-2020 Regulation provides direct support for EU foreign policies by increasing the effectiveness and coherence of EU action in the areas of crisis response, conflict prevention, peacebuilding and crisis preparedness, and in dealing with global and transregional threats. ${ }^{47}$ Through the said Regulation, as well as through the Regulation amending Regulation (EU) no. 230/2014 establishing an instrument contributing to stability

the definition and role of mediation, see Julian Bergmann, The European Union as International Mediator, Brokering Stability and Peace in the Neighbourhood, 9.

${ }^{45}$ Ibid., 3.

${ }^{46}$ On the European Union's foreign policy instruments, see Who's Who, accessed 2 May 2020, https://ec.europa.eu/fpi/about-fpi/who\%E2\%80\%99s-who_en,

${ }^{47}$ Regulation (EU) no. 230/2014 of the European Parliament and of the Council establishing an instrument contributing to stability and peace [2014] OJ L 77 
and peace of 12 December 2017, the EU will clearly and unambiguously present its own foreign policy views and objectives, as well as support mechanisms, all with the aim of proving to the actual/desired extent how it can manage crises in the future and how it is ready to be a global factor in peacebuilding. Therefore, the objectives for which the Regulation is adopted are laid down in Article 1 (4) and read as follows:

- in crisis situations or emerging crisis situations, to contribute quickly to stability by providing an effective response designed to help maintain, establish or re-establish the conditions essential for the proper implementation of the Union's external policies and actions in accordance with Article 21 of TEU;

- contribute to conflict prevention and ensure capacity and preparedness to resolve pre- and post-crisis situations and build peace; and

- act in accordance with specific global and transregional threats to peace, international security and stability ${ }^{48}$

- providing support for security sector actors in third countries, inter alia, in exceptional circumstances, the military, in the context of conflict prevention, crisis management or stabilization, is key to ensuring appropriate conditions for poverty eradication and development. ${ }^{49}$

Based on the set objectives, the same EU Regulation will list the types of assistance it will provide for the implementation of the objectives, as well as the determinants of the Common Foreign and Security Policy and the Common Security and Defence Policy, so we can clearly conclude the differences in the policy of implementing the EU's own objectives, in the correlation of time in 1993 and 2020. Therefore, by the provision of Article 4 (1) of the Regulation, and under the chapter Assistance to conflict-prevention, peacebuilding and crisis preparedness, the EU will clearly define what that assistance is;

"The Union provides technical and financial assistance with a view to meeting the specific objectives set out in Article 1 (4) (b). This assistance includes support for measures aimed at building and strengthening the capacity of the Union and its partners to prevent conflict, build peace and meet pre- and post-crisis needs in close cooperation with the United Nations and other international, regional and sub-regional organizations, national actors and civil society actors in terms of their efforts to:

(a) promote early warning and risk analysis in terms of conflict in policy making and implementation;

48 Ibid.

${ }^{49}$ REGULATION (EU) 2017/2306 OF THE EUROPEAN PARLIAMENT AND OF THE COUNCIL amending Regulation (EU) no. 230/2014 establishing an instrument contributing to stability and peace, [2017] OJ L 335/6 
(b) facilitate and strengthen capacities in the context of confidence-building, mediation, dialogue and reconciliation, with a special focus on inter-community tensions;

(c) strengthen the capacities to participate and engage in civilian stabilization missions". 50

Based on the Concept on Strengthening EU Mediation and Dialogue Capacities, Regulation of the European Parliament and of the Council establishing an instrument contributing to stability and peace and Regulation amending Regulation (EU) no. 230/2014 establishing an instrument contributing to stability and peace, the EU will functionally and through the legally and historically upgraded and reformed own legal system upgrade the mechanisms in the establishment and building of peace, both in Europe and in the world. Although the stated and factual legal and historical sequence of the development of sources of law that will complement and strengthen European efforts to establish peace compared to 1993, the reality of the unresolved situation in Ukraine, namely in the "neighborhood" of the European Union to this day leaves open the question of sufficiency and effectiveness of sources and their content, from which the mechanisms of conflict prevention, establishment and building of peace between the conflicting parties arise. The EU's inability to resolve conflicts and achieve lasting peace and solution among conflicting parties, as in the case of Ukraine, raises the question of whether the EU can realistically be a global political player in 2020 in the context of peace-building. ${ }^{51}$

The European Parliament Resolution of 12 March 2019 on building EU capacity on conflict prevention and mediation accurately and unambiguously presents the EU's foreign policy priorities and mechanisms in the implementation of peace. In this context, in the chapter "On strengthening the EU's institutional

${ }^{50}$ Regulation (EU) no. 230/2014 of the European Parliament and of the Council establishing an instrument contributing to stability and peace, author's comment.

${ }^{51}$ In the context of the armed conflicts from 2014 in Ukraine, a peace agreement was reached through three negotiating formats in Geneva, Normandy and Minsk. The European Union participated only in the Geneva peace negotiations in which Ukraine, Russia, the European Union and the United States participated. On the Geneva peace negotiations, see "Ukraine crisis: Geneva talks produce agreement on defusing conflict", accessed 26 April 2020, https://www.theguardian. com/world/2014/apr/17/ukraine-crisis-agreement-us-russia-eu

The fact that the European Union did not participate in the final negotiations and peace agreements regarding the Ukrainian crisis, Minsk I and Minsk II, but that France and Germany participated independently without the European Union, speaks volumes about the real power of the European Union to manage crises and establish peace on European soil. For more on the agreements Minsk I and Minsk II see Ole Elgström, Natalia Chaban, Michèle Knodt, Patrick Müller and Sharon Pardo, "Perceptions of the EU's Role in the Ukraine-Russia and the Israel-Palestine Conflicts: A Biased Mediator?", International Negotiation, Vol 23, Issue 2 (April 2018): 304. and 305., DOI: https://doi.org/10.1163/15718069-23021154 
capacity for conflict prevention and mediation", the EU's objectives and mechanisms will therefore be: to support more consistent and comprehensive EU engagement in external conflicts and crises, and for the EU to consider an integrated approach to external conflicts and crises as an added value to the EU's external action, and that all means must be applied as quickly as possible in order to clarify the EU's responses at each stage of the conflict and make this integrated approach more operational and effective. In the implementation of the aforementioned, the EU refers to the norms and principles of international law and the UN Charter, which enables us to see that the provisions of international law form an integral part of the European public law/normative corpus in peacekeeping, namely in the procedures for establishing and building peace. Furthermore, the text of the Resolution calls for the establishment of other inter-institutional mechanisms, such as working groups for specific conflict prevention situations, in order to fully strengthen the EU due to the complexity of the situation in the world. The establishment of a special EEAS Department for Conflict Prevention, Peacebuilding and Mediation Instruments also supports this. Geopolitical circumstances and security challenges from the end of the decade (end of 2019, author's comment) The EU will, through the same document, demand greater allocations for conflict prevention and the provision of dedicated staff, as well as emphasizing the need to ensure sufficient and targeted funding for EU action in conflict prevention and mediation in the next multiannual financial framework (2021-2027). ${ }^{52}$ Following the above Resolution, the foreign policy reality of European action in the establishment and building of peace or peace action from the end of 2019 and the beginning of 2020, despite the dispersion of legal sources and norms, as well as their content, from which the mechanisms of peace action arise, the reality of the EU's foreign policy peacekeeping and peacebuilding will be reflected in the European Parliament's annual Report on the implementation of the Common Security and Defence Policy of 11 December 2019. The reality and the very implementation of European foreign policy peacekeeping in the world refers to the fact that the EU is late in responding and adapting, in political, diplomatic and military terms, to new crises and the new international context, and is considered to have insufficient investments in the specific field of defence, lack of capabilities and lack of interoperability, but above all political reluctance to implement the strict provisions of the European treaties and numerous forms of cooperation between Member States. Such circumstances, as stated in the same Report, make it impossible for the EU to play a decisive role in managing external crises and reach its full potential, and calls on Member States to devise an effective integrated approach to crises and conflicts combining civilian and military assets to the best possible balanced way. Therefore,

${ }^{52}$ European Parliament Resolution of 12 March 2019 on building EU capacity on conflict prevention and mediation, [2018] 2159(INI) 
the Report offers some solutions that should eliminate the identified shortcomings in the action itself, and primarily it is thought that the EU should be able to adequately respond to new crises and conflicts, and that it does not depend on the speed of decision-making, and any future action should continue to be exclusive and in accordance with the principles of the UN Charter and the Common Foreign and Security Policy (CFSP). ${ }^{53}$

Following what is presented in this part of the paper through legal and historical presentation of legal sources and their contents (both the Lisbon Treaty and other legal determinants of European and international public law), from which the mechanisms available to the EU in the process of conflict prevention, establishment and building of peace arise, there is no doubt that the evolutionary progress in the content of a particular legal source provides greater operational and other opportunities for European foreign policy action in this context, in relation to the fact of the European peace action in 1993. Despite building its own legal system that will offer the operational and other power of European peacekeeping in establishing peace in the world in relation to the formal-legal and operational power(lessness) of 1993, through the example of Ukraine as a glaring example of European inability to act in peacebuilding in its own "neighborhood", the reality of the latest Report to the European Parliament on the implementation of the Common Security and Defence Policy will follow not only the author's opinion, but will also confirm the author's opinion by Juncos and Blockmans, who state the following: "Yet, despite the legal and rhetorical commitment to preventing and responding to conflicts, present EU data leave room for improvement." 54

\section{CONCLUDING OBSERVATIONS}

Comparing legal sources, their content, from which the legal basis for action and the mechanisms of foreign policy peace action in the establishment and building of peace of the European Union from its founding in accordance with the Maastricht Treaty to the present day will emerge, imposes the conclusion of evaluation development of legal sources, contents that derive from the same sources and thus mechanisms for European peace actions in conflict prevention, establishment and peace building. The European Union's Action Plan for finding a peace solution among the conflicting parties in Bosnia and Herzegovina and resolving the issue of "modus vivendi" in the Republic of Croatia was the last independent test of peace action of the European Economic Community and the newly established

\footnotetext{
${ }^{53}$ European Parliament, Report on the implementation of the common security and defence policy - annual report [2019] 2135(INI)

${ }^{54}$ Ana E. Juncos, Steven Blockmans, The EU's role in conflict prevention and peacebuilding: four key challenges, 131 .
} 
European Union at a time of its global proving that it is capable of managing crises independently and reaching a solution among the conflicting parties. The failure of the Action Plan will reflect on the questioning of the reach and possibility of EU foreign policy and the European Union's real strength as a global player in international relations, especially in the areas of crisis management and peacebuilding, both in Europe and in the world. Therefore, based on historical facts, and guided by the idea and desire to become a global political player, the European Union will through the "Reform Treaties" (Treaty of Amsterdam and Treaty of Nice), as well as through the Lisbon Treaty normatively and thus institutionally give new strength to the European Union to achieve the objectives of the Common Foreign and Security Policy in the context of international peacekeeping operations. The reality of the time lag of almost three decades, namely the comparison of time in 1993 and 2020, speaks in favor of European normative development, especially through the Lisbon Treaty, which will not only provide the necessary legal basis for peacekeeping, but will also build institutes for future peace actions of the European Union in the processes of establishing and building peace in the desired global environment. Such a fact will not only reflect the totality of foreign policy action and the expansion of European peacekeeping in the establishment and building of peace, either through peace mediations or participation in military and civilian missions around the world, but will also begin to prove those determinants of the objectives for which the European Union was founded.

Without entering into the legal and historical description of individual European Union peacekeeping activities since 1993 and the collapse of the last independent European peacekeeping operation in the former Yugoslavia, the content of legal sources and thus the mechanisms that enable peacekeeping, given the fact of the unresolved "Ukrainian Question", as well as through the last Report in the European Parliament on the implementation of the Common Foreign and Security Policy, will raise the question of whether the current legal sources and their content, from which the mechanisms for conflict prevention and peacebuilding derive, are sufficient for the realization of the EU's foreign policy goals, and whether they have the necessary power to implement declaratory decisions in real time. Although a normative step forward has been made in European legal sources that will provide wider opportunities for the introduction of new mechanisms in peacekeeping, all in accordance with the determinants of European and international public law, with the aforementioned "Ukrainian Question", the reality of global relations and threats, as well as the opening of new crisis hotspots around the world, will leave open the question of real European foreign policy achievements in the process of establishing and building peace among the conflicting parties. Therefore, in the context of drawing a parallel between 1993 and 2020, the author believes that there is a significant normative, and thus institutional step forward of the European 
Union in terms of crisis management and peacebuilding in accordance with European public law and international legal determinants, but the reality of the aforementioned Report and the actual state of affairs in Europe (in the "neighborhood" of the European Union) and in the world leaves open the question of whether these legal sources and their content, and the resulting peace mechanisms, are sufficient to achieve the objectives of the EU's Common Foreign and Security Policy and the European Union itself.

\section{REFERENCES}

Books and articles

Andrassy, Juraj, Bakotić, Božidar, Seršić Maja, Vukas, Budislav. Međunarodno pravo I. Zagreb: Školska knjiga, Zagreb, 2010.

Bergmann, Julian, The European Union as International Mediator, Brokering Stability and Peace in the Neighbourhood, palgrave macmillan, Palgrave studies in European union Politics, Switzerland, 2020.

Bluth, Christoph., Germany and the Future of European Security, Macmillan Press LTD, London, 2000.

Dagen, Tomislav, Pravnopolitički mehanizmi za sprječavanje sukoba i postizanje mira na prostoru bivše Jugoslavije od 1990. - 1995., Doctoral School of the University of Osijek, Osijek, 2018, PhD Thesis.

Elgström, Ole, Chaban, Natalia, Knodt, Michèle, Müller, Patrick i Pardo, Sharon, „Perceptions of the EU's Role in the Ukraine-Russia and the Israel-Palestine Conflicts: A Biased Mediator?“, International Negotiation, Vol 23, Issue 2 (April 2018), DOI: https://doi.org/10.1163/15718069-23021154

Ginsberg, H. Roy, The European Union in International Politics; baptism by fire, Rowman \& Litllefield Publisher, 2001.

Handbook on the Peaceful Settlement of Disputes between States, United Nations, New York, 1992.

Herrberg, Antje, International Peace Mediation: A New Crossroads for the European

Union, ur. Philip Vorre, ISIS Europe, ISIS Europe and Geneve Centre for the Democratic Control of Armed Forces, 2012.

Herdegen, M., Europsko pravo, Faculty of Law in Rijeka, Rijeka, 2002, pp. 110-135. Holbrooke, Richard, Završiti rat, Šahinpašić, Sarajevo, 1998.

Jovanović, Vladislav, Rat koji se mogao izbeći, Nolit, Beograd, 2008.

Juncos E. Ana, Blockmans Steven, "The EU's role in conflict prevention and peacebuilding: four key challenges", Global Affairs, Routledge, Volume 4 (2018): 131, https://doi.org/10.1080/23340460.2018.1502619

Owen, David, Balkanska odiseja, Hrvatska sveučilišna naklada, Croatian Institute of Historx, Zagreb, 1998.

Palm,Trineke, Crum, Ben, "Military operations and the EU's identity as an international security actor", European Security, Vol 28, No 4, (2019): 514, https://doi. org/10.1080/09662839.2019.1667769 
Rudolf, D. ml., Zajednička sigurnosna i obrambena politika Europske unije prema Lisabonskom ugovoru, Proceedings of the Faculty of Law in Split, yr. 51, 3/2014.

Schachinger, Johannes, European External Action Service Engagement in Mediation and Mediation Support, Tamminen, T. (ed.), Strengthening the EU's peace mediation capacities Leveraging for peace through new ideas and thinking, Ulkopoliittinen instituutti, Utrikespolitiska institutet, The Finnish Institute of International Affairs, Helsinki, 2012.

Tardy, Thierry, The European Union and UN Peace Operations: What Global-Regional Peace and Security Partnership in United Nations Peace Operations in a Changing Global Order, ed.: Cedric de Coning, Mateja Peter, Palgrave Macmillan, 2019.

Väyrynen, Tarja, The higher cause of peace': what could and should the Nordic countries contribute to the development of conflict mediation in the EU context?, The Nordic countries and the European Security and Defence Policy, edited by Bailes, Alison, J.K, Herolf, Gunilla and Sundelius, Bengt, Oxford University Press, 2006.

Vukadinović, Radovan, Čehulić, Lidija, Politika europskih integracija, Topical, Zagreb, 2005.

\section{EEC/EU Regulations}

Cologne European Council, Presidency Conclusions. Annex III. [ON-LINE]. [s.1.]: [6 June 2003]. Press: 0 Nr: 150/99

Council of the European Union, Concept on Strengthening EU Mediation and Dialogue Capacities, Brussels, 10 November 2009.

Conclusions of the Helsinki European Council: extract concerning preparations for enlargement (10-11 December 1999.)

Conflict Prevention - Council conclusions, COUNCIL OF THE EUROPEAN UNION, Brussels, 20 June 2011.

EPC bulletin, Vol 9, 1993., pp. 551., 552.

European Parliament Resolution of 12 March 2019 on building EU capacity on conflict prevention and mediation, [2018] 2159(INI)

European Parliament, Report on the implementation of the common security and defence policy - annual report [2019] 2135(INI)

European Security Strategy/ A SECURE EUROPE IN A BETTER WORLD, COUNCIL OF THE EUROPEAN UNION Brussels, 8 December 2003, 15895/03

Global Strategy for the European Union's Foreign and Security Policy "Shared Vision, Common Action: A Stronger Europe", EU Summit 28 June 2016, pp. 11.

IN-DEPTH ANALYSIS, CSDP Missions and Operations, European Parliament, January 2020.

Publication of European Commission, European Peace Facility, 13 June 018.

Single European Act, Official Journal of the European Communities No L 169, 29. 6. 1987.

Treaty of Amsterdam amending the Treaty on European Union, the Treaties establishnig the European Communities and certain related acts, OJ EC, C 340/01, 10 November 1997

Treaty on European Union, [1992] OJ C 191 Volume 35 
Treaty of Lisbon amending the Treaty on European Union and the Treaty establishing the European Community [2007] OJ C 306/01

Treaty of Nice amending the Treaty on European Union, the Treaties establishing the European Communities and certain related acts, signed at Nice, 26 February 2001, OJ EC, C 80, Volume 44, 10 March 2001

Regulation (EU) no. 230/2014 of the European Parliament and of the Council establishing an instrument contributing to stability and peace [2014] OJ L 77

Regulation (EU) 2017/2306 of the European Parliament and of the Council amending Regulation (EU) no. 230/2014 establishing an instrument contributing to stability and peace, [2017] OJ L 335/6

Websites

Conclusions of the Helsinki European Council: extract concerning preparations for enlargement (10-11 December 1999), https:/www.europarl.europa.eu/summits/ hell en.htm

Conflict Prevention, Peace building and Mediation, https:/eeas.europa.eu/topics/ conflict-prevention-peace-building-and-mediation/426/conflict-prevention-peace-building-and-mediation_en

European Council in Brussels - 29 October 1993 Presidency Conclusions, https:// ec.europa.eu/commission/presscorner/detail/en/DOC 93 7,)

European Parliament, Common Foreign and Security Policy, $\overline{\mathrm{h}} \mathrm{ttps}: / / \mathrm{www}$.europarl. europa.eu/factsheets/hr/sheet/159/zajednicka-sigurnosna-i-obrambena-politikaEuropski parlament, http://www.europarl.europa.eu/factsheets/hr/sheet/6/izvori-i-podrucje-primjene-prava-europske-unije

ESDI, Separable but not separate?, 1 July 2000/ NATO Review. https://www.nato. int/docu/review/articles/2000/07/01/esdi-separable-but-not-separate/index.htm

EU in the World, https://eeas.europa.eu/headquarters/headquarters-homepage/area/geo_en EU Missions and Operations As part of the EU's Common Security and Defence Policy (CSDP):https:/www.eca.europa.eu/sites/eca-audit defence/EN/Documents/ EU\%20Missions\%20and\%200perations.pdf

“Gulf Fighting Shatters Europeans' Fragile Unity", "The New York Times”, 1991.., http:/www.nytimes.com/1991/01/25/world/war-in-the-gulf-europe-gulf-fightingshatters-europeans-fragile-unity.html

UN Charter., https://www.un.org/en/charter-united-nations/

An overview of current EU missions and operations., https://eeas.europa.eu/headquarters/headquarters-homepage/430/military-and-civilian-missions-and-operations en

Treaty establishing the European Economic Community/Treaty of Rome., http:/eurlex.europa.eu/legal-content/HR/TXT/?uri=CELEX:11957E/TXT

"Ukraine crisis: Geneva talks produce agreement on defusing conflict". https://www. theguardian.com/world/2014/apr/17/ukraine-crisis-agreement-us-russia-eu

University of Liverpool/The Balkan Odyssey Digital Archive, http://sca-arch.liv.ac.uk/ $\mathrm{ead} / \mathrm{html} / \mathrm{gb} 141$ boda-p1.shtml\#boda.1.05.1.

United States Department of State, The Breakup of Yugoslavia, 1990-1992, https:// history.state.gov/milestones/1989-1992/breakup-yugoslavia

Who's Who, https://ec.europa.eu/fpi/about-fpi/who\%E2\%80\%99s-who_en 
Др Томислав Б. Даїен

Универзитетеи Јосийа Јурја Шӣросмајера у Осијеку

Акаяемија за умјеитности и куличуру у Осијеку

tdagen@net.hr

\section{Правноисторијска гледишта правних извора за успостављање и изградњу мира ЕЕЗ/ЕУ на простору бивше Југославије 1993. године и европских реалитета 2020. године}

Сажейак: Послеgње мировно йосреgовање Евройске економске зајеgниие йуием Евройске йолитичке сараяње, као и йочейак деловања Заједничке сйољне и безбеgносне йолитиике Евройске уније с 1. новембром 1993. іояине на ирростиор бивще Јуїославије ояразиће се кроз Акиијски йлан (Јуйӥѐ-Кинкелов йлан). Такав йослеgњи самостиални йокущај ЕЕЗ-а/ЕУ у усйосйављану и изіраяњи мира йуйем мировног йосредовања имаће своје уйорищйе у йравним изворима. Учинци мировноі йосреgоваға кроз Акиијски йлан биће оgраз саgржаја и досеїа ирравних извора и ирроизащлих механизама из исииих извора. Неусиех Акиијскои йлана, gаће нову димензију сиољнойолиичичкоі деловања ЗСБП да йуиеем мировноі йосреgовањ а усиоостиави и изіраяи мир међу сукобљеним сииранама. У йом смислу, ауйор ће као ирредмей самої истираживања у овом раяу комйаратиивном, истиоријском и метиооом анализе, а кроз иризму ирравноистиоријских іллеgищӣа иовући йаралелу између 1993. іолине и 2020.

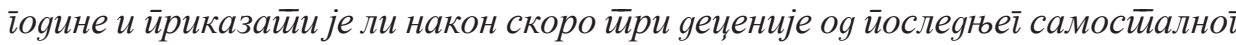

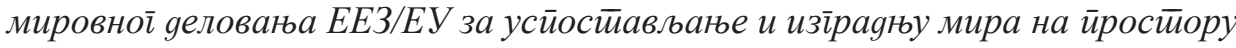
бивще Југославије, ЕУ уиркос жељи gа буgе іллобални факіиор у усйостиављању

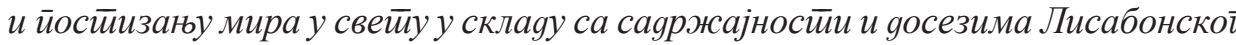

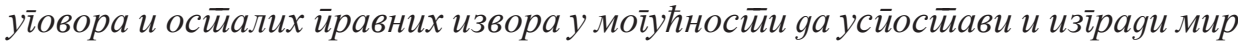
међу сукобљеним сииранама.

Кључне речи: Евройска унија, Акцијски йлан, Лисабонски уі̄овор, усйост̄ивљање мира, мировно йосреgовање.

Датум пријема рада: 10.07.2020. 